\title{
Changing the Religiosity of Indonesian Muslims in the New Normal
} Era

\author{
Abdul Halim ${ }^{1 *}$, Nadirsyah Hosen ${ }^{2}$ \\ 1 Faculty of Da'wa and Communication, UIN Sunan Ampel Surabaya, Indonesia; e-mail: halim@uinsby.ac.id \\ 2 Faculty of Law, Monash University, Australia; e-mail: nadirsyah.hosen@monash.edu \\ * Correspondence
}

Received: 2021-04-16; Accepted: 2021-05-11; Published: 2021-07-31

\begin{abstract}
This study examined new religious patterns and behaviours in Indonesian Muslims during the New Normal era. This new religiosity is an impact of government regulations and recommendations from community organisations regarding social and physical distancing restrictions due to the spread of Covid-19. This study used a sociological approach to analyse changes in religious and social behaviour of Indonesian Muslims in public spaces qualitatively. This study found five main aspects that indicate a new form of religiosity for Indonesian Muslims in the New Normal era, namely; a shift in worship practices from a public space to a private space, a decrease in the capacity of the physical space that has an impact on decreasing the routine of worship, the emergence of new challenges for the authorities and public policy to prepare an area for more personal religious activities, the disappearance of symbolic worship practices, and finally, the blurring of abangan Muslim groups based on waqi'iyah (contemporary/contextual) ijtihad. These findings are analysed using the theory of public space from Jurgen Habermas's. This study proposes a new pattern of religiosity for Indonesian Muslims in the New Normal era, i.e., the adjustment of Shari'a by way of independent legal reasoning to maintain a wider maslahat, public welfare.
\end{abstract}

Keywords: Indonesian Muslims; new normal; new religiosity; public and private space.

\begin{abstract}
Abstrak: Penelitian ini mengkaji tentang pola dan perilaku keberagamaan baru Muslim di Indonesia selama masa Kebiasaan Baru atau disebut juga New Normal. Pola keberagamaan baru ini muncul sebagai dampak dari regulasi pemerintah yang kemudian didukung oleh organisasi keagamaan berkaitan dengan penjagaan jarak secara sosial dan individual karena pandemic Covid-19. Penelitian ini menggunakan pendekatan sosiologi untuk menganalisis perubahan yang terjadi dalam perilaku beragama dan sosial masyarakat Muslim di Indonesia secara kualitatif. Penelitian ini menemukan lima hal yang dapat dikategorikan sebagai bentuk keberagamaan baru Muslim Indonesia di masa New Normal. Di antaranya adalah: pergeseran praktek ibadah yang tadinya dilaksanakan di tempat umum menjadi di ruang pribadi, pengurangan kapasitas pertemuan fisik yang kemudian berpengaruh kepada berkurangnya rutinitas ibadah, munculnya tantangan baru bagi para pemangku kebijakan untuk menyiapkan ruang ibadah pribadi, hilangnya praktek-praktek ibadah simbolis, dan tersamarkannya identitas kelompok Muslim abangan sebagai hasil dari ijtihad waqi'iyah (ijtihad kontekstual). Hasil penelitian ini dianalisis dengan menggunakan teori public space dari Jurgen Habermas. Penelitian ini merekomendasikan bahwa terdapat perilaku keberagamaan baru yang dilakukan oleh Muslim Indonesia pada masa New Normal yakni diberlakukannya penyesuaian hukum sebagai hasil dari ijtihad demi kemaslahatan umat.
\end{abstract}

Kata Kunci: keberagamaan baru; kebiasaan baru; Muslim Indonesia; ruang public dan pribadi. 


\section{Introduction}

Since Covid-19 becomes a public problem, this medical case significantly impacts changing social life, including changing human travel behaviour (Chakraborty \& Maity, 2020). In the context of Islam, Covid-19 is the reason for the delay of the journey of Muslims to perform the Hajj and Umrah pilgrimage. The postponement of the Hajj and Umrah pilgrimage implementation has a political force from the Kingdom of Saudi Arabia as the sole authority for the performance of the Hajj and Umrah pilgrimage. The travel cooperation agreement among the Gulf countries had to be delayed (Ebrahim \& Memish, 2020b). The substantial reason for the postponement of the Hajj and Umrah pilgrimage trips is to avoid the mass crowds of pilgrims. Meanwhile, Covid-19 will spread more massively because of mass gatherings (Ebrahim \& Memish, 2020a).

Furthermore, Covid-19 triggers a "socio-religious conflict," namely the birth of pro-contra public response behaviour. Several religious groups have responded to government policies in handling Covid-19. Since March 2020, some religious communities have supported the government's social and physical distancing policies. However, some other groups oppose it (Darmawan, Miharja, Waluyajati, \& Isnaeniah, 2020). This occurrence is not only in Indonesia but also in other countries like South Korea (Her, 2020). The Covid-19 issue is also manipulated to generate terrorism movements (Ong \& Azman, 2020) globally and in Indonesia (Arianti \& Taufiqurrohman, 2020). It impacts socio-economic changes, such as job losses for vulnerable social groups and women workers (Wenham, Smith, \& Morgan, 2020).

Covid-19 threatens social space and activities. One of them is the public's demand for the government of Saudi Arabia to prepare the implementation of the Hajj and Umrah pilgrimages (McLoughlin, 2020; Oktavianti, 2020). Shahul H. Ebrahim dan Ziad A. Memish said that Covid-19 has a great potential to spread when pilgrims come to the city of Makkah. For this reason, the Saudi Arabian government immediately took policies and early preparation because it is possible for the pilgrims to ignore the health of their homeland (Ebrahim \& Memish, 2020b). Because of this, the Indonesian government policy of not dispatching pilgrims is considered appropriate.

Efforts to postpone the routine of worship in public spaces such as the holy Kaaba site are a challenge on the religious dimension and based on the health of Muslims in the future. The violation of keeping a distance is believed to reduce the quality of the perfection of the Hajj/Umrah pilgrimage itself. Qanta A. Ahmed and Ziad A. Memish (2020), who has monitored the health of the Hajj/Umrah pilgrims for the last 15 years, stated that mass gathering is a huge potential for the spread of the pandemic. Consequently, massive gatherings in public spaces must be prevented early as possible.

As one of the countries affected by Covid-19, Indonesia has its response and policies. Here, public reaction to this religious issue is mixed and controversial. Some groups see that limiting social space is an act of intervention against their religious beliefs. Meanwhile, some other religious groups agree with this policy. According to Riyanti Djalante, et al. (2020), Covid-19 has changed public behaviour in three routinely: staying at home, washing hands more often, and implementing distancing.

The group that views the policy of keeping distance as an attack on religious beliefs is a minority group. Meanwhile, the majority groups such as Nahdlatul Ulama (NU) and Muhammadiyah organisations are pro-government policy. Implementing a lockdown is expected to anticipate the spread of a pandemic in Indonesia (Yunus \& Rezki, 2020).

The Nadhlatul Ulama National Executive Board (PBNU) issued policies that support the government, such as an instruction letter number 3953/ C.I.034.04.3030 that instructed the Muslims to perform tarawih during Ramadhan month and celebrate Eid at home. The Tarjih and the Tajdid Council of PP Muhammadiyah also issued a similar instruction number 02 / EDR / I.0 / E / 2020. These two mass organisations agree that all religious worship activities in the public space are temporarily moved to the private sphere (Nuryanti, 2020).

The prohibition by the government and suggestions from mass organisations to reduce gathering activities for the implementation of religious activities are preventive measures, which have an impact on decreasing the capacity of physical space. The instruction includes that the places of worship such as mosques in Indonesia can only accommodate half of the congregation capacity. This decline in the 
capacity of prayer rooms occurs in Islam and other religions of the Hindu, Jewish, and Christian communities (Diseko, 2020).

Generally, Indonesian Muslims are divided into such categories as abangan, priyayi, and santri (Mulkhan, 2003). According to some sources, this religious practice of the abangan tends to worship only as a practical rite. In fact, until the 1950s, these abangan Muslims were not familiar with Eid alAdha (Simon, 2004). With the negated implementation of the Eid al-Fitri prayer in 2020, abangan Muslims cannot do it. The Eid al-Fitri prayer service is the only moment for the abangan to prove their Islamic existence.

All the dynamics and changes in social life above, theoretically, can be called changes in the religiosity of Indonesian communities. Based on the understanding of Rodney Stark and Charles Y. Glock, religiosity is the commitment of religious people to manifest their beliefs in the forms of their daily activities. A person's religiosity is signed by a commitment to religious teachings in one daily action. Changes in social behaviour, thus, can be called changes in religiosity (Stark \& Glock, 1968).

Some of the religiosity dimensions that can change are knowledge, belief, worship practices, and appreciation. This change can occur because it follows the function of religiosity for human needs, including education, saviour, peace, social supervision, solidarity, and social transformation (Glock \& Stark, 1965). Thus, this study focuses on the changes in the religiosity of Indonesian Muslims in the new normal era; namely, a change that leads to an increasingly stable and established pattern and process so that it deserves to be called a new form of religiosity.

This research is a qualitative inductive type. It means that patterns, themes, and categories emerge from the data. Propositions are developed, ideas are put forward during the data collection stage, and data analysis is carried out afterward. The new data finding is to confirm previous propositions are still widely open (Daymon \& Holloway, 2007). In the context of this study, data were collected from documents combined with observations of researchers in the field, especially in the great mosques of Surabaya, especially the Al Akbar National Mosque.

\section{Religiosity and the Public Space}

Until this article is written, Indonesia has entered a New Normal era. Step by step, the socioreligious behaviour of the Indonesian Muslim community has also begun to make adjustments to the government regulations and recommendations from community organisations to prevent the transmission of Covid-19. One by one, the public saw that the mosques and prayer rooms were empty of worshipers compared to the days before the pandemic as something normal. Indeed, this should be the pattern of religious behaviour in the New Normal era. Such propositions are put forward and critically analysed, and new data are continuously being collected to confirm or correct these propositions. For this reason, inductive qualitative research is a suitable choice to study the problem of the new religious behaviour of Indonesian Muslims.

Considering that government policies and recommendations from Islamic mass organisations in Indonesia focus more on maintaining social distancing and physical distance for medical versions of health goals, social space is important. For this reason, this study uses the theory of the public sphere from Jurgen Habermas.

In an introduction to Habermas' work, Thomas McCarthy defines the public sphere as a critical space that discusses thinking between the version of civil society and the views of the democratic state (Habermas, 1991). For Jurgen Habermas, "Sociology continues to study public opinion," namely studying public opinion that is struggling in the public sphere (public sphere). Regarding this public opinion, Habermas discussed the state as a "public authority," a public authority, which is tasked with promoting the welfare and prosperity of the people (Habermas, 1991, p. 398).

This public space is essential for the government and mass organizations, to limit the public crowd to prevent congregational activities that accumulate in one place and prevent the spread of the Covid19 pandemic. The bargaining of ideas in the public sphere reflects the social system of nation and state, both at the national and global levels, as a healthy and democratic system. Pros and cons occur, even if 
the winner has been determined from the beginning, namely the government. For Habermas, the government or state is a symbol of public authority.

In this public space, Habermas formulated two essential words: lexis and praxis. Lexis is a discussion or bargaining of ideas (idea). In further developments, this idea also included laws, and in the end, manifested into a standard action. This joint action is called praxis in the public space (Habermas, 1991). Similarly, social distancing and physical distancing are international ideas rolled out by scientists, both medical experts and social and humanities studies. In Indonesia particularly, and several other countries, this idea has been translated into government regulations and calls from Islamic organisations, so that Muslims inevitably have to follow it simultaneously.

This research will focus on the forms of Muslim praxis that try to interpret the ideas from the government and mass organisations regarding the prevention of the spread of the pandemic, along with all the logical consequences that arise later due to this form of praxis. This research calls this logical consequence a "new religiosity" of Indonesian Muslims in the New Normal era. This phenomenon emerges as a result of the implementation of all the ideas of the government regulation and progovernment Islamic organisations regarding the Pandemic situation.

The religiosity referred to in this sociological research means a religious matter that has four principles; first, a religious tradition that is limited to material things; second, religious phenomena that are selected and determined; third, the context of religious phenomena, and fourth, explicit religious concepts that drive religious transmission (Whitehouse, 2004). These four principles are used to determine a new form of religiosity as a new practice of Indonesian Muslim diversity that follows government regulations and recommendations from religious organisations that occur in the context of preventing the Covid-19 epidemic in the new normal. For this reason, this new religiosity can be examined both visually and materially.

\section{The Shift of Worship Practices from Public Spaces to Private Spaces}

Charles Y. Glock and Rodney Stark stated that change in religiosity begins with knowledge, belief and then leads to changes in religious behaviour. The goal is none other than education, social rescue, and social protection (Glock \& Stark, 1965). In this context, this shift in practice from the public space to the private space due to the spread of Covid-19 and the issuance of government regulations and religious fatwas from authoritative religious institutions. So that inevitably, people must change their religious behaviour patterns to conform to state regulations and fatwas of religious institutions.

With the issuance of Government Regulation (PP) Number 21 of 2020 concerning Large-Scale Social Restrictions in the Context of Accelerating the Handling of Corona Virus Disease 2019 (COVID19) (President of the Republic of Indonesia, 2020), stipulated, promulgated, and effective since March 31, 2020, more robust normative suggestions emerge from religious mass organisations with the enormous mass in Indonesia, such as Nahdlatul Ulama and Muhammadiyah. Circular letters from NU and Muhammadiyah align with the government's vision and mission in preventing pandemics (Nuryanti, 2020). For instance, Vice Chairman of MUI, Zainut Tauhid Sa'adi, stated that people in DKI Jakarta are not allowed to have a Friday sermon but change it into Dhuhr's prayer during the Covid-19 pandemic. This decision could be read in Fatwa MUI Number 14 the Year 2020 on Praying Implementation Along Covid-19 Pandemic (Farisa, 2020).

As the characteristics of the public space - even though it has been confirmed early that the winner will be the government and pro-government mass organisations - there is still resistance to the hegemony of the government's ideas and NU-Muhammadiyah mass organisations. Although only a few organisations show resistance, their existence and voices are quite significant. It is what in Jurgen Habermas language is a democratic public space. The public has an equal opportunity to present their respective opinions freely and without pressure. This opportunity does not focus on win-lose affairs between majority and minority. As long as there is freedom of thought in the public sphere, the public sphere is democratic and healthy. This public criticism against the government has gone viral on the internet (Gimmler, 2001). 
Public resistance that had gone viral on the internet was arrested by the Executive Director of The Indonesian Institute, Centre for Public Policy Research (TII), Adinda Tenriangke Muchtar. She also said that without everyone's awareness and compliance, this lockdown policy would not be effective. She also presented the findings that since April 10, 2020, there were still a group of people who had not complied with the implementation of the lockdown policy. Moreover, the violation by the community is in the name of the economy. In the end, Adinda also tolerated and considered the violation of society with economic reasons as a matter of fate. The solution thereof is effective socialisation and firm law enforcement (Purnamasari, 2020).

The resistance from the community is getting fainter day by day, and in the end, the implementation of social distancing and physical distancing restrictions is rolling smoothly. An example is the implementation of Eid al-Fitri in the homes of each Indonesian Muslim. The government has received support from traditional religious institutions in Indonesia, such as the Indonesian Ulema Council (MUI), including NU and Muhammadiyah (Bramasta, 2020).

As an appreciation, President Jokowi expressed his gratitude and expressed his admiration for mass organisations and the solid community with the government to help each other prevent the spread of the Covid-19 pandemic. According to President Joko Widodo, the government has received a lot of assistance and support from various circles of society. Many initiatives have emerged from each community and the government to fight Covid-19 (Albanna, 2020).

Since then, the public discussion ended. The selected opinion is the idea of carrying out the urgency of maintaining social and physical distancing to prevent the Covid-19 pandemic. Consequently, all forms of religious ritual that require large crowds in the form of swarming must be prevented. Even if it is forced to continue to be carried out in the congregation, it is necessary to comply with existing protocols regulated by the government. In the language of Jurgen Habermas, lexis follows an idea (Habermas, 1991).

\section{Decreasing the Capacity of Physical Space and Worship Routine}

When Muslims obey the government's protocols and fatwas of religious authorities, it does not mean that problems would not appear. As Charles Y. Glock and Rodney Stark put it, belief and knowledge are followed by social action (Stark \& Glock, 1968). Social action in this context is the obedience of Indonesian Muslims to the protocol of Covid-19 handling from the government and fatwas from religious institutions to maintain physical distance (Sulistiadi, Slamet, \& Harmani, 2020). Physical space problems also arise for example in decreasing the physical space capacity due to the length that must be maintained. A reduction follows the reduction of physical space capacity in the routine of worship.

Achmad Yurianto, the government's spokesman for the handling of Corona Covid-19, said, "there was a significant increase in cases, namely 153 cases. It illustrates that there is still transmission; there is still close contact. The government's recommendation to maintain distance must be obeyed. Keep a distance of at least two meters. Conversely, physical space of fewer than 1.5 meters will provide the opportunity for transmission from the people who are diagnosed carry the virus to other vulnerable people" (Prastiwi, 2020) The government's version of the view is in line with the advice of medical experts (Repici et al., 2020).

One example of managing a mosque's place of worship that meets government protocols in preventing Covid-19 is the Al Akbar Mosque, Surabaya (Al Maliki et al., 2021). Jusuf Kalla (JK), as the General Chairperson of the Indonesian Mosque Council, appreciated the management of the Al Akbar Mosque, Surabaya, and called it an example of managing places of worship in the New Normal era. One example, the Al Akbar Mosque applies the concept of "Green Toilet MAS," applying detailed health protocols, and the mosque team is equipped with personal protective equipment (PPE) (Arfani, 2020).

Meanwhile, the Secretary of the Al Akbar Mosque, Helmy M. Noor, explains that from the beginning, his party had implemented standard operating procedures for health protocols according to government directions, namely implementing 14 SOPs, including maintaining distance, storing 
sandals in a special drawer, and shortening Friday sermons to ten minutes. Besides, the mosque is cleaned five times a day (Fakhruddin, 2020).

Two essential points that make the Surabaya Al Akbar Mosque is considered an ideal example of mosque management in the New Normal era are keeping the distance (two meters) according to government directives and shortening the duration of Friday sermons to ten minutes, where previously was longer. In other words, this is a new form of religiosity in the New Normal era, namely a reduction in physical space capacity and a decrease in the tempo of routine worship (sermons). This new form of religiosity has reflected ideal activities in the public space (Arfani, 2020).

Patricia Aelbrecht and Quentin Stevens (2019) say, "Public spaces should ideally be inclusive to protect cultural diversity, create the spatial experience of democracy, reduce potential social conflicts, reintegrate a socio-spatially fragmented city, expand citizenship, empower a community, get people involved in the governance and maintenance of their cities and public space and ultimately promote an urbanism of tolerance and social cohesion".

In this context, the Al Akbar Mosque is a model that reduces the physical space capacity of the mosque on the grounds of following the government's health protocol. Besides, reducing the tempo of religious rituals such as the Friday sermon is a new form of Muslim religiosity in the New Normal era that seeks to openly respect democracy and reduce social conflicts that may arise from an antigovernment public, and integrate religious interests and the government's policies. Al Akbar Mosque of Surabaya, by implementing the Green Toilet, provides an example of how this new religiosity can integrate social into government health and political programs, especially the prevention of the Covid19 pandemic.

\section{Challenge in Preparing "New Space" for "New Religiosity" Activities}

New religiosity practice in the New Normal era is not without challenges. When physical distancing has been enforced in mosques, such as the pilot mosque (Masjid Al Akbar Surabaya), the problem emerges in preparing a new space/room that followed the changing following the regulation. Preparing new space is needed to organise religious activities in the New Normal era.

The need for the availability of a new prayer room as a substitute for the existing room is addressed by labourers and office workers. In 2018, according to Airlangga Hartarto, Minister of Industry, "the manufacturing sector absorbed a workforce of 18.25 million." The Ministry of Industry claims that the number of labour absorption by the manufacturing sector has continued to increase in the last four years. For example, in 2015, 15.54 million workers were recorded, 2016 increased to 15.97 million workers, and 2017 increased again to 17.56 million workers (Jannah, 2019).

When entering the New Normal era, and these workers return to their duties to work in the industrial sector, they need new spaces to worship as directed by government regulations, namely to keep their distance. In fact, in maintaining distance, there must be a reduction of the crowd in the area. Meanwhile, the decrease in the space for places of worship demands a change. Because when Muslims are unable to optimally utilise the mosques, prayer rooms, or other public areas of prayer, they need alternative spaces to work on new patterns of religiosity according to regulations in the New Normal era.

The government's call to hold worship with distance in this normal era is based on the implementation of Article 80 of Law Number 13 of 2003 concerning workers (Law 13/2003). The article mentions the right for everyone to worship: "Entrepreneurs are obliged to provide adequate opportunities for workers/laborers to carry out the worship required by their religion." Meanwhile, the explanation for Article 80 of Law 13/2003 states that it is meant by sufficient opportunity to provide a place to perform worship that allows workers/labourers to perform their worship adequately based on the conditions and capabilities of the company (Hutomo, 2019).

Article 80 of Law 13/2003 emphasises the "ability of companies" to provide worship places for employees. The ability can be interpreted as the provision of a new area of worship in exchange for the old space that was insufficient due to being reduced capacity following the application of government regulations on keeping distance. The capacity of places of worship is not enough due to the 
government's health protocol demands "replacement," namely the creation of new rooms or widening the room. The procurement of new prayer rooms is not an easy matter. It is not just a matter of budget availability but rather a matter of limited land or area. To restore the original space capacity before being reduced by the rules of keeping physical distance and fixing the size of the volume of the existing room by adding new rooms is the mandate of Article 80 of Law 13/2003.

Without creating a new space as a substitute, transferring religious activities to the private area becomes difficult while reducing the existing place (Ozalp, 2020). Muslims must return to exploiting the old regions; one of the reasons is that the company cannot carry out the law's mandate on the one hand, while on the other hand, government regulations require a reduction of activities in the existing space. Implementing these two laws cannot be carried out simultaneously because new religious activities demand new space.

Maria Farida Indrati Soeprapto said a statutory regulation could only be revoked and declared invalid by statutory rules of the same or higher level (Soeprapto, 2018). Government Regulation (PP) Number 21 of 2020 concerning Large-Scale Social Restrictions in the Context of Accelerating Handling of Corona Virus Disease 2019 (COVID-19) has the potential to be challenging to implement in the context of carrying out the mandate of Article 80 of Law 13/2003.

Physical distancing must be done to prevent pandemic transmission. However, keeping a distance of up to two meters will have an impact on reducing space capacity. A reduced space implements worship disturbed because there is no available room for worship. Meanwhile, Article 80 of Law $13 / 2003$ instructs the provision of prayer rooms for employees, and companies cannot afford it due to limited land to build new spaces. Government Regulations (PP) and worker Act are challenges in the New Normal period, especially to organise new religious activities.

\section{New Religiosity: The End of Symbolic Worship Practices}

The new religiosity in carrying out worship while maintaining social and physical distance can eliminate some symbolic worship practices. One form of extended worship is related to maintain close/tight distance of rows of saff (prayer lines) as a form of prayer perfection (Al-Musainid, 2007), and shaking hands after the prayer (Shihabuddin, 2013). All these symbolic forms of worship have disappeared because of government regulations regarding social and physical distancing. More than that, there is also support from Islamic organisations for the policy of the Covid-19 eradication program by the Government based on Ijtihad Waqi'iyah (contextual/contemporary).

Ijtihad Waqi'iyah is a search for law from sources of Islamic law because of the natural and contextual problems faced by society. Muhammad Hasan Najafi (1981, p. 129) conveyed his views on the meaning of "real public welfare (masalih waqi'iyah)." According to him, the law that is in line with the Islamic vision results from a study taking into account the basic needs of society. Here, Islamic law (Shari'a) can issue fatwas. It is called Ijtihad Waqi'iyah (Contemporary Independent Legal Reasoning).

One of the ijtihad waqi'iyah products is circular number 105-Khusus / PP-DMI / A / Vl / 2020 from the Indonesian Mosque Council (DMI) that signed by Jusuf Kalla. The result of ijtihad has been distributed to the public since June 16, 2020. The contents of the brochure are the implementation of Friday prayers with two waves or shifts. Then, the congregation arrangement who can join the prayer is based on the cellular phone number by calculating the even and odd numbers (Mashabi, 2020b). This kind of religious behaviour had never occurred before, mainly before Covid-19 emerged as a Muslim public pandemic. In practice, implementing this appeal is not easy. Worshipping at the mosque feels more and more complicated. Because of this complexity, not many mosques have followed DMI's call. As an effort, what DMI is doing is an offer for limited physical space for worship. However, in terms of law and the belief of Muslims for the perfection and even the validity of worship, further study needs to be conducted in this aspect. This practice proves that the issue of worship practices as a marker of one's religiosity is not permanently attached to the normative rules of the government or religious organizations. Religiosity is a private matter. However, strengthening religiosity can be obtained from communal worship, namely congregation in mosques and prayer rooms. Meanwhile, the physical 
space of the mosque and prayer room is no longer sufficient to accommodate all of the community as before because worship must follow a protocol of maintaining distance.

Since the significant mass organisations in Indonesia (MUI, NU, Muhammadiyah, DMI, etc.) have voted for and supported the government, the website has been overwhelmed with new analyses related to several issues like shaking hands and tight rows of prayer. Anwar Abbas, Secretary-General of the Indonesian Ulema Council, said, "Guarding yourself against falling into disasters and calamities is obligatory while shaking hands is only a sunnah. So those things that we do not want to happen in the form of the spread and transmission of the coronavirus because one of the most effective ways of spreading this virus is through shaking hands" (Mashabi, 2020a).

The loss of this symbolic worship practice is also called a change in an old religiosity towards a new form of religiosity. This unique experience of religiosity is a phenomenon within the country and throughout the Muslim world. One of them happened among British Muslim congregations. At four large mosques in Burton, England, caretakers appealed to congregants not to hug or shake hands after praying. The four mosques are the Jamia Hanfia Ghausia Mosque, the Makki Mosque, the York Street Mosque, and the Rizvia Central Jamia Mosque on Uxbridge Street, Burton. The goal is the same, according to the chairman of the Jamia Hanafia Ghausia Mosque, Shaukat Mahmood, is to anticipate the spread of the coronavirus (Muhyiddin, 2020). In Islam, making the law following the changing times is legal (Sumitro, Kumkelo, \& Kholish, 2014).

In other words, the new religiosity of Indonesian Muslims in this New Normal era has followed complete legitimacy instruments, both in terms of politics in the form of government policies, the social consensus in the form of support from religious authority institutions such as MUI, NU, Muhammadiyah, and others, as well as a philosophical foundation of law in Islam like Figh and Usul Fiqih. New Religiosity is a new social phenomenon in the New Normal era. These new habits of religiosity to become a new order for Muslims in worship will still take a long process. In this context, it seems relevant that religiosity, as conceptualised by Charles Y. Glock and Stark Rodney, is educational and transformative. The religious elite is morally obliged to provide education to Muslims to maintain the religiosity of Muslims. As for the public, high religiosity results in educational and transformative social practices and behaviours.

\section{Obfuscation of Muslim Abangan Group}

Clifford Geertz's sociologist classifies Indonesian Muslims into santri, priyayi, and abangan. These three categories are not easy to distinguish when the New Normal regulation is implemented. In terms of the practice of praying in public spaces, it is the abangan people who have been very conspicuous compared to Muslim santri (Ali-Fauzi, Bagir, \& Rafsadi, 2017), since entering the New Normal era, they have a solid legitimacy to appear as they are. It does not mean denying the quality of the abangan group's beliefs but rather symbolising their religious practice, namely prayer (Nugroho, 2020).

As previously mentioned, since Eid Al-Fitr prayer in 2020 is carried out in the homes of each resident, Muslim santri and Muslim abangan will be undetectable with variables in the form of the implementation of Eid prayers that are not carried out in mosques or halls. Does it mean that if Eid prayer is not practised in public spaces, it cannot be seen whether an abangan also performs Eid prayers in their respective homes? Meanwhile, based on common practice, as said by Asep Nurjaman, the fundamental characteristic of these abangan is that they often leave the five daily prayers (Nurjaman, 2019).

They strictly carry out the five daily prayers that can only be seen if it is performed in public spaces, namely mosques and prayer rooms. So that people who are not or rarely seen praying in public spaces tend to be considered abangan. However, when performing the five daily prayers, Friday prayers, tarawih (Ramadan night) prayers, and holiday prayers are recommended to be completed in each resident's house, the indicator of strict worship no longer applies. This assumption, namely the labelling of abangan to people who do not pray in congregation at the mosque, actually cannot be used as the only reference. It is just that it needs to be understood that prayer is the most straightforward indicator to see one's obedience in religion. It is because prayer is both physical and spiritual worship, which the 
congregation highly recommends doing. In this context, congregational prayer in public places of worship has advantages, namely the multiple values of prayer and the performance of Muslims, thus giving birth to a new spirit in religion.

Meanwhile, the recommendation to divert places of worship from public to private spaces can be called "privatisation" of prayer. This privatisation implies that it obscures the stark differences between Muslim santri and Muslim abangan due to government regulations and circulars from Islamic mass organizations. Suppose it turns out that the new order, namely worship in a private space, results in a decrease in religiosity, especially for the abangan group. In that case, it is a challenge to the government, Islamic organisations, and religious elites. Religious spirit in Indonesia is an integral part of building the character of society and the nation. Indonesia is not a country based on religion. However, Indonesia protects and respects the rights of the people in religion according to their beliefs. In this case, mosques and prayer rooms are strategic places for Muslims in forging their identity as Muslims and as well as good citizens

\section{Conclusion}

The New Normal era creates a new pattern of religiosity and creates new challenges as a direct or indirect consequence. This new challenge, for example, is the need to provide private space when all religious activities are recommended to be carried out in private spaces. The new order should be followed by a new spatial policy for mosques and prayer rooms. Without government policies, Muslims will find it very difficult to meet the availability of places of worship according to the new rules. If the government neglects this matter, it can result in the birth of the Muslim community's disappointment. Another challenge also occurs in the legal realm; one law requires prayer rooms according to the company's capacity level. It is constrained by the problem of the limited land available to provide new space. So that carrying out health protocol procedures regulated by government regulations is harder in this case, except for ignoring the law. Ignorance of the law, in any perspective, is the beginning of chaos, and it must be avoided.

Another aspect to be paid attention to is related to the loss of cultural aspects, such as Muslim santri identities. It is increasingly blurred to be distinguished from abangan Muslims, or Muslim identities from a particular flow that is difficult to differentiate from another Muslim. For example, the practice of symbolic worship of tight rows of saff prayers and shake hands after prayer is an example of extended worship change. These practices are lost because of government regulations and fatwas from ijtihad waqi'iyah of the ulama, leading to pro-social-physical distancing during the pandemic era. The Muslims, however, should respect and adjust to this new regulation to maintain a wider maslahat, public welfare.

\section{References}

Aelbrecht, P., \& Stevens, Q. (2019). Public space design and social cohesion: An international comparison. London: Routledge. https://doi.org/10.4324/9780429489150

Ahmed, Q. A., \& Memish, Z. A. (2020). The cancellation of mass gatherings (MGs)? Decision making in the time of COVID-19. Travel Medicine and Infectious Disease, 34, 101631. https://doi.org/10.1016/j.tmaid.2020.101617

Al-Musainid, S. A. A. bin N. (2007). Panduan Beribadah Khusus Pria. Jakarta: Almahira.

Al-Najafi, M. H. (1981). Jawahir al-Kalam. Qom: Dar Ihya Torath Arabi.

Al Maliki, M., Hilmy, A., Muslimin, J., Kamarusdiana, K., Asmawi, A., \& Asriati, A. (2021). The Fiqh of Pandemic: The Arguments and Practices of Worship at the Al Akbar National Mosque in Surabaya. Proceedings of the 3rd International Colloquium on Interdisciplinary Islamic Studies, ICIIS 2020, 20-21 October 2020, Jakarta, Indonesia, 1-12. EAI. https://doi.org/10.4108/eai.20-10-2020.2305150

Albanna, M. S. (2020). Jokowi Salut dengan Solidaritas Masyarakat dan Ormas. Retrieved 12 May 2021, from Tagar website: https://www.tagar.id/jokowi-salut-dengan-solidaritas-masyarakat-dan-ormas

Ali-Fauzi, I., Bagir, Z. A., \& Rafsadi, I. (2017). Kebebasan, Toleransi dan Terorisme (Riset dan Kebijakan Agama di Indonesia). Jakarta: Pusat Studi Agama dan Demokrasi (Yayasan Paramadina).

Arfani, F. (2020). JK: Masjid Al Akbar jadi percontohan tempat ibadah era normal baru. Retrieved 12 June 2021, from Antara News website: https://www.antaranews.com/berita/1559496/jk-masjid-al-akbar-jadi- 
percontohan-tempat-ibadah-era-normal-baru

Arianti, V., \& Taufiqurrohman, M. (2020). Security Implications of COVID-19 for Indonesia. Counter Terrorist Trends and Analyses, 12(3), 13-17.

Bramasta, D. B. (2020). MUI, NU, dan Muhammadiyah Imbau Pelaksanaan Shalat Idul Fitri di Rumah, Berikut Tata Caranya. $\quad$ Retrieved 15 May 2021, from Kompas website: https://www.kompas.com/ramadhan/read/2020/05/23/175700872/mui-nu-dan-muhammadiyah-imbaupelaksanaan-shalat-idul-fitri-di-rumah?page=all

Chakraborty, I., \& Maity, P. (2020). COVID-19 outbreak: Migration, effects on society, global environment and prevention. Science of The Total Environment, 728, 138882. https://doi.org/10.1016/j.scitotenv.2020.138882

Darmawan, D., Miharja, D., Waluyajati, R. S. R., \& Isnaeniah, E. (2020). Sikap Keberagamaan Masyarakat Menghadapi Wabah COVID-19. Religious: Jurnal Studi Agama-Agama Dan Lintas Budaya, 4(2), 115-124. https://doi.org/10.15575/rjsalb.v4i2.8596

Daymon, C., \& Holloway, I. (2007). Metode-metode riset kualitatif dalam public relations dan marketing communications. Yogyakarta: Bentang Pustaka.

Diseko, L. (2020). Virus corona: Apa dampak Covid-19 terhadap tata cara ibadah agama? Retrieved 12 June 2021, from BBC Indonesia website: https://www.bbc.com/indonesia/indonesia-51813486

Djalante, R., Lassa, J., Setiamarga, D., Sudjatma, A., Indrawan, M., Haryanto, B., ... Warsilah, H. (2020). Review and analysis of current responses to COVID-19 in Indonesia: Period of January to March 2020. Progress in Disaster Science, 6, 100091. https://doi.org/10.1016/j.pdisas.2020.100091

Ebrahim, S. H., \& Memish, Z. A. (2020a). COVID-19 - the role of mass gatherings. Travel Medicine and Infectious Disease, 34, 101617. https://doi.org/10.1016/j.tmaid.2020.101617

Ebrahim, S. H., \& Memish, Z. A. (2020b). Saudi Arabia's drastic measures to curb the COVID-19 outbreak: temporary suspension of the Umrah pilgrimage. Journal of Travel Medicine, 27(3), taaa029. https://doi.org/10.1093/jtm/taaa029

Fakhruddin, M. (2020). JK: Masjid Al Akbar Jadi Percontohan di Era Normal Baru. Retrieved 12 June 2021, from Republika website: https://www.republika.co.id/berita/qc2ra4327/jk-masjid-al-akbar-jadi-percontohan-diera-normal-baru

Farisa, F. C. (2020). Waketum MUI: Muslim di Jakarta Boleh Tak Shalat Jumat akibat Covid-19. Retrieved 12 June 2021, from Kompas website: https://nasional.kompas.com/read/2020/04/03/11013941/waketum-mui-muslimdi-jakarta-boleh-tak-shalat-jumat-akibat-covid-19

Gimmler, A. (2001). Deliberative democracy, the public sphere and the internet. Philosophy E Social Criticism, 27(4), 21-39. https://doi.org/10.1177/019145370102700402

Glock, C. Y., \& Stark, R. (1965). Religion and society in tension. Chicago: Rand McNally.

Habermas, J. (1991). The structural transformation of the public sphere: An inquiry into a category of bourgeois society. Massachusetts: MIT press.

Her, M. (2020). How Is COVID-19 Affecting South Korea? What Is Our Current Strategy? Disaster Medicine and Public Health Preparedness, 14(5), 684-686. https://doi.org/10.1017/dmp.2020.69

Hutomo, D. (2019). Adakah Dasar Hukum Penyediaan Tempat Ibadah di Kantor? Retrieved 12 May 2021, from hukumonline.com website: https://m.hukumonline.com/klinik/detail/1t5d01df23dd8ab/adakah-dasarhukum-penyediaan-tempat-ibadah-di-kantor/\#: :text=Hak untuk memeluk agama dan,dikatakan sebagai tindak pidana kejahatan.

Jannah, S. M. (2019). Menperin: Industri Manufaktur RI Serap 18,25 Juta Pekerja pada 2018. Retrieved 12 April 2021, from Tirto website: https://irto.id/menperin-industri-manufaktur-ri-serap-1825-juta-pekerja-pada2018-dg8e

Mashabi, S. (2020a). Cegah Covid-19, Sekjen MUI Imbau Umat Islam Tak Bersalaman Silaturahim Saat Idul Fitri. Retrieved 15 May 2021, from Kompas website: https://nasional.kompas.com/read/2020/05/15/11234401/cegah-covid-19-sekjen-mui-imbau-umat-islam-takbersalaman-silaturahim-saat

Mashabi, S. (2020b). DMI Atur Shalat Jumat 2 Gelombang Berdasarkan Ganjil Genap Nomor Ponsel. Retrieved 12 June 2020, from Kompas website: https://nasional.kompas.com/read/2020/06/16/22560661/dmi-atur-shalatjumat-2-gelombang-berdasarkan-ganjil-genap-nomor-ponsel?page=all

McLoughlin, S. (2020). Hajj 2020: coronavirus pandemic frustrates Saudi vision for expanded religious tourism. Retrieved 12 May 2021, from The Conversation website: https://theconversation.com/hajj-2020-coronaviruspandemic-frustrates-saudi-vision-for-expanded-religious-tourism-141142

Muhyiddin. (2020). Masjid di Burton Imbau Jamaahnya tak Berpelukan dan Salaman. Retrieved 12 April 2021, from Republika website: https://www.republika.co.id/berita/q79vx0366/masjid-di-burton-imbaujamaahnya-tak-berpelukan-dan-salaman 
Mulkhan, A. M. (2003). Moral politik santri: agama dan pembelaan kaum tertindas. Jakarta: Erlangga.

Nugroho, A. (2020). UGM Sociologist: The New Normal Primary Prerequisite Health Infrastructure Infrastructure. Retrieved 12 June 2020, from Universitas Gadjah Mada website: https://www.ugm.ac.id/en/news/19465ugm-sociologist-the-new-normal-primary-prerequisite-health-infrastructure-infrastructure

Nurjaman, A. (2019). Partai dan Pemilu: Perilaku Politik di Aras Lokal Pasca Orde Baru (Vol. 1). Malang: UMM Press. Nuryanti. (2020). PBNU dan PP Muhammadiyah Imbau Warga Salat Tarawih dan Idulfitri di Rumah jika Masih Pandemi Corona. Retrieved 12 May 2021, from Tribun News website: https://www.tribunnews.com/corona/2020/04/06/pbnu-dan-pp-muhammadiyah-imbau-warga-salattarawih-dan-idulfitri-di-rumah-jika-masih-pandemi-corona

Oktavianti, T. I. (2020). COVID-19: Govt hopes Saudi Arabia will announce decision on haj soon. Retrieved 25 May 2021, from The Jakarta Post website: https:/www.thejakartapost.com/news/2020/05/08/covid-19-govthopes-saudi-arabia-will-announce-decision-on-haj-soon.html

Ong, K., \& Azman, N. A. (2020). Distinguishing Between the Extreme Farright and Islamic State's (IS) Calls to Exploit COVID-19. Counter Terrorist Trends and Analyses, 12(3), 18-21.

Ozalp, M. (2020). How coronavirus challenges Muslims' faith and changes their lives. Retrieved 2 April 2021, from The Jakarta Post website: https://www.thejakartapost.com/life/2020/04/02/how-coronavirus-challengesmuslims-faith-and-changes-their-lives.html

Prastiwi, D. (2020). Jubir: Jaga Jarak 2 Meter Cegah Penularan Corona Covid-19. Retrieved 12 June 2021, from Liputan6 website: https://www.liputan6.com/news/read/4212840/jubir-jaga-jarak-2-meter-cegah-penularancorona-covid-19

President of the Republic of Indonesia. Government Regulation (PP) Number 21 of 2020 concerning Large-Scale Social Restrictions in the Context of Accelerating the Handling of Corona Virus Disease 2019 (COVID-19). , (2020).

Purnamasari, D. M. (2020). Kepatuhan dan Kesadaran Masyarakat, Kunci agar PSBB Berjalan Efektif. Retrieved 13 April 2021, from Kompas website: https://nasional.kompas.com/read/2020/04/13/14055471/kepatuhan-dankesadaran-masyarakat-kunci-agar-psbb-berjalan-efektif?page $=$ all

Repici, A., Maselli, R., Colombo, M., Gabbiadini, R., Spadaccini, M., Anderloni, A., ... Lagioia, M. (2020). Coronavirus (COVID-19) outbreak: what the department of endoscopy should know. Gastrointestinal Endoscopy, 92(1), 192-197. https://doi.org/10.1016/j.gie.2020.03.019

Shihabuddin, A. (2013). Membongkar Kejumudan: Menjawab Tuduhan-Tuduhan Salafi Wahhabi. Jakarta: Noura Books.

Simon, H. (2004). Misteri Syekh Siti Jenar: peran wali songo dalam mengislamkan tanah Jawa. Yogyakarta: Pustaka Pelajar.

Soeprapto, M. F. I. (2018). Ilmu Perundang-undangan 2: Proses dan Teknik Penyusunan. Yogyakarta: PT Kanisius.

Stark, R., \& Glock, C. Y. (1968). American piety: The nature of religious commitment (Vol. 1). Berkeley: University of California Press.

Sulistiadi, W., Slamet, S. R., \& Harmani, N. (2020). Management of COVID-19 Public Stigma in Indonesian Society. Kesmas: National Public Health Journal, 15(2), 70-76. https://doi.org/10.21109/kesmas.v15i2.3909

Sumitro, W., Kumkelo, M., \& Kholish, M. A. (2014). Politik Hukum Islam: Reposisi Eksistensi Hukum Islam dari Masa Kerajaan Hingga Era Reformasi di Indonesia. Universitas Brawijaya Press.

Wenham, C., Smith, J., \& Morgan, R. (2020). COVID-19: the gendered impacts of the outbreak. The Lancet, 395(10227), 846-848. https://doi.org/10.1016/S0140-6736(20)30526-2

Whitehouse, H. (2004). Modes of religiosity: A cognitive theory of religious transmission. Maryland: Rowman Altamira. Yunus, N. R., \& Rezki, A. (2020). Kebijakan Pemberlakuan Lock Down Sebagai Antisipasi Penyebaran Corona Virus Covid-19. Salam: Jurnal Sosial Dan Budaya Syar-I, 7(3), 227-238. https://doi.org/10.15408/sjsbs.v7i3.15083

(C) 2021 by the authors. Submitted for possible open access publication under the terms and conditions of the Creative Commons Attribution (CC BY SA) license (https://creativecommons.org/licenses/by-sa/3.0/). 
This page is intentionally left blank 